\title{
Impact of microbiological changes on spontaneous bacterial peritonitis in three different periods over 17 years
}

\author{
Paulo Roberto Lerias de ALMEIDA ${ }^{1,2}$, Gabriel Stefani LEÃ $0^{1}$, Charlles David Gonçalves GONÇALVES ${ }^{1}$, \\ Rafael Veiga PICON ${ }^{1,3}$ and Cristiane Valle TOV0 ${ }^{1,2}$
}

\begin{abstract}
Background - Spontaneous bacterial peritonitis is a serious complication in cirrhotic patients, and changes in the microbiological characteristics reported in the last years are impacting the choice of antibiotic used for treatment. Objective - The aim of the present study is to evaluate the changes in the epidemiology and bacterial resistance of the germs causing spontaneous bacterial peritonitis over three different periods over 17 years. Methods - All cirrhotic patients with spontaneous bacterial peritonitis and positive culture of ascites fluid were retrospectively studied in a reference Hospital in Southern Brazil. Three periods were ramdomly evaluated: 1997-1998, 2002-2003 and 2014-2015. The most frequent infecting organisms and the sensitivity in vitro to antibiotics were registered. Results - In the first period (1997-1998) there were 33 cases, the most common were: E. coli in 13 (36.11\%), Staphylococcus coagulase-negative in $6(16.66 \%)$, K. pneumoniae in $5(13.88 \%)$, S. aureus in $4(11.11 \%)$ and $S$. faecalis in $3(8.33 \%)$. In the second period (2002-2003), there were 43 cases, the most frequent were: Staphylococus coagulase-negative in $16(35.55 \%)$, $S$. aureus in $8(17.77 \%)$, E. coli in $7(15.55 \%)$ and K. pneumoniae in $3(6.66 \%)$. In the third period (2014-2015) there were 58 cases (seven with two bacteria), the most frequent were: E. coli in $15(23.1 \%)$, S. viridans in $12(18.5 \%)$, K. pneumoniae in $10(15.4 \%)$ and E. faecium 5 (7.7\%). No one was using antibiotic prophylaxis. Considering all staphylococci, the prevalence increased to rates of the order of $50 \%$ in the second period, with a reduction in the third period evaluated. Likewise, the prevalence of resistant $E$. coli increased, reaching $14 \%$. Conclusion - There was a modification of the bacterial population causing spontaneous bacterial peritonitis, with high frequency of gram-positive organisms, as well as an increase in the resistance to the traditionally recommended antibiotics. This study suggests a probable imminent inclusion of a drug against gram-positive organisms in the empiric treatment of spontaneous bacterial peritonitis.
\end{abstract}

HEADINGS - Peritonitis. Bacterial infections. Liver cirrhosis. Ascites.

\section{INTRODUCTION}

Spontaneous bacterial peritonitis (SBP) is defined as the infection of ascites fluid in patients with cirrhosis, in the absence of apparent abdominal focus of infection ${ }^{(1)}$. Its prevalence in cirrhotic patients with ascites on hospital admission ranges from $10 \%$ to $30 \%{ }^{(2)}$. The risk of developing SBP during hospitalization ranges from $20 \%$ to $60 \%$, with mortality from $20 \%$ to $40 \%{ }^{(3)}$. Treatment failure occurs in about $10 \%$, leading to a poor prognosis with hospital mortality from $50 \%$ to $80 \%{ }^{(4)}$. The probability of recurrence is $43 \%$ in 6 months, and the 2-year survival rate is only $50 \%{ }^{(1)}$.

The culture of ascites fluid is negative in more than $60 \%$ of cases, when using conventional techniques, even in the presence of suggestive clinical manifestations. The use of blood culture bottles to inoculate the collected material allows an increase of up to $90 \%$ in the chance of obtaining a positive culture ${ }^{(4)}$.

Over $60 \%$ of SBP episodes are caused by enteric gram-negative bacteria, and the most common germs isolated were Escherichia coli (E coli) and Klebsiella pneumoniae (K. pneumoniae). Gram-positive germs are present in $25 \%$ of SBP episodes, with streptococcal spe- cies being the most frequently isolated ${ }^{(5)}$. However, considerable change in the epidemiology of germ causing SBP has occurred. This alteration has been attributed to increased survival, increased invasive procedures and prolonged use of antibiotics for intestinal decontamination $^{(3,6)}$.

The preponderance of infections caused by Gram-negative bacteria due to epidemiological changes has shifted to a higher prevalence of infections being caused by gram-positive cocci ${ }^{(6)}$. The use of systemic antibiotics within 30 days before SBP diagnosis and a lower Sequential Organ Failure Assessment (SOFA) score were independent predictors of SBP caused by Gram-positive bacteria in patients with cirrhosis ${ }^{(7)}$. In the study by Alexopoulou et al. ${ }^{(8)}$ and Almeida et al. ${ }^{(9)}$, the majority of isolated pathogens from patients with SBP were gram-positive cocci.

Thus, changes in the microbiological characteristics reported in recent years may have an impact on the choice of empirical treatment.

The objectives of the present study are to evaluate the changes in the epidemiology and bacterial resistance of the germs causing SBP in three different periods over 17 years in a specialized tertiary care general hospital in Southern Brazil. 


\section{METHODS}

The evaluated population consists of patients hospitalized at the Hospital Nossa Senhora da Conceição - Porto Alegre, Brazil, a public tertiary hospital. All cases of cirrhotic patients with SBP in which culture of ascites fluid was positive were retrospectively evaluated. Three different periods randomly assessed were studied: 19971998, 2002-2003 and 2014-2015. The most frequent microorganisms and in vitro susceptibility to antibiotics were verified, as well as the presence or absence of chemoprophylaxis. All the bacteria that grew in the culture were reported in each period. Identification of the bacterial samples and the antimicrobial susceptibility test were performed by the automated Microscan ${ }^{\circledR}$ test (Dade Behring, WalkAway-96). The use of previous quimioprophylaxis against SBP was also searched in the charts.

For statistical analysis, the chi-square test was used to compare the proportions between Gram-positive and Gram-negative microorganisms in the two evaluated periods, using the Epi-Info Program. Chi-square for non-linearity was used to assess non-linear trend between proportions of Gram-negatives and Gram-positives cultures across the three periods under study. Alpha was set at 5\%.

\section{RESULTS}

In the first period evaluated (1997-1998) 33 cases of SBP with positive culture were identified, with $3(9.1 \%)$ polymicrobial infections. The most frequent bacteria were E. coli in $13(36.1 \%)$, coagulase-negative staphylococci in $6(16.2 \%), K$. pneumoniae in 5 $(13.9 \%)$, Staphylococus aureus (S. aureus) in $4(11.1 \%)$ and Enterococcus faecalis (E. faecalis) with $3(8.3 \%)$ cases.

In the second period (2002-2003), 43 cases of SBP were identified, of which $2(4.6 \%)$ were polymicrobial. The most common germs were coagulase-negative staphylococci in $16(35.5 \%)$ cases, S. aureus in 8 $(17.8 \%)$, E coli in $7(15.5 \%)$ and $K$. pneumoniae in $3(6.7 \%)$.

In the third period (2014-2015) 58 cases of SBP were identified, being $7(12.1 \%)$ polymicrobial. The most frequent germs were $E$ coli in $15(23.1 \%)$ cases, Streptococcus viridans $(S$. viridans) in 12 $(18.5 \%)$, K. pneumoniae in $10(15.4 \%)$ and Enterococcus faecium (E. faecium) in $5(7.7 \%)$.

The total number of Gram-negative germ was 20 (55.6\%), 16 $(35.6 \%)$ and $34(52.3 \%)$ in the first, second and third study periods, respectively. The number of Gram-positive patients was 16 $(44.4 \%), 29(64.4 \%)$ and $31(47.7 \%)$ in the first, second and third study periods, respectively.

Other germs identified are described in TABLE 1.

The comparison of the three evaluated periods showed a decrease in the proportion of Gram negative in the second period followed by a new increase in the third period (i.e. $55.6 \%$ in the first, $35.6 \%$ in the second and $52.3 \%$ in the third periods), representing a significant non-linear trend across the three periods $(P=0.043)$.

No patient was on prophylaxis for SBP at the time of hospitalization. With respect to bacterial resistance rates, the complete spectrum in the three periods analyzed is shown in TABLE 2.

The prevalence of methicillin-resistant $S$. aureus (MRSA) increased from $25 \%$ to $75 \%$ between the first and second periods, which implies the same levels of resistance to other $\beta$-lactam antibiotics such as cephalosporins I and III generation. In the third period, there was no resistance of $S$. aureus to oxacxilin, although the resistance rates of coagulase-negative Staphylococci were progressively higher. Only the vancomycin remained $100 \%$ active against $S$. aureus and S. coagulase negative during the analyzed periods.
TABLE 1. Germs causing SBP in the first (1997-1998), second (20022003) and third (2014-2015) periods evaluated

\begin{tabular}{|c|c|c|c|c|c|c|}
\hline \multirow[b]{2}{*}{ Bacteria } & \multicolumn{2}{|c|}{ 1st Period } & \multicolumn{2}{|c|}{ 2nd Period } & \multicolumn{2}{|c|}{ 3rd Period } \\
\hline & $\mathbf{N}$ & $(\%)$ & $\mathbf{N}$ & $(\%)$ & $\mathbf{N}$ & $(\%)$ \\
\hline Escherichia coli & 13 & $(36.1)$ & 7 & $(15.5)$ & 15 & $(23.1)$ \\
\hline $\begin{array}{l}\text { Staphylococcus } \\
\text { coagulase-negative }\end{array}$ & 6 & $(16.7)$ & 16 & $(35.5)$ & 2 & $(3.1)$ \\
\hline Klebsiella pneumonia & 5 & (13.9) & 3 & $(6.7)$ & 10 & $(15.4)$ \\
\hline Staphylococcus aureus & 4 & $(11.1)$ & 8 & $(17.8)$ & 2 & $(3.1)$ \\
\hline Enterococcus faecalis & 3 & $(8.3)$ & 0 & - & 4 & $(6.2)$ \\
\hline Streptococcus viridans & 0 & - & 2 & $(4.4)$ & 12 & $(18.5)$ \\
\hline Enterococcus faecium & 0 & - & 0 & - & 05 & $(7.7)$ \\
\hline Enterococcus avium & 1 & $(2.8)$ & 0 & - & 0 & - \\
\hline Streptococcus bovis & 1 & $(2.8)$ & 0 & - & 0 & - \\
\hline $\begin{array}{l}\text { Pseudomonas } \\
\text { aeruginosa }\end{array}$ & 1 & $(2.8)$ & 0 & - & 2 & $(3.1)$ \\
\hline Salmon/Arizona & 1 & $(2.8)$ & 0 & - & 0 & - \\
\hline Klebsiella oxytoca & 0 & - & 2 & $(4.4)$ & 0 & - \\
\hline Acinetobacter sp. & 0 & - & 2 & $(4.4)$ & 0 & - \\
\hline $\begin{array}{l}\text { Streptococcus } \\
\text { agalactiae }\end{array}$ & 0 & - & 1 & $(2.2)$ & 1 & $(1.5)$ \\
\hline Enterobacter cloacae & 0 & - & 1 & $(2.2)$ & 1 & $(1.5)$ \\
\hline Kluyvera ascorbata & 0 & - & 1 & $(2.2)$ & 0 & - \\
\hline Enterococcus spp. & 0 & - & 0 & - & 1 & $(1.5)$ \\
\hline $\begin{array}{l}\text { Leuconostoc } \\
\text { pseudomesentoroides }\end{array}$ & 0 & - & 0 & - & 1 & (1.5) \\
\hline Hafnia alvei & 0 & - & 0 & - & 1 & $(1.5)$ \\
\hline Haemophilus specie & 0 & - & 0 & - & 1 & (1.5) \\
\hline Pantoea specie & 0 & - & 0 & - & 1 & $(1.5)$ \\
\hline Citrobacter freundi & 0 & - & 0 & - & 1 & $(1.5)$ \\
\hline $\begin{array}{l}\text { Streptococcus } \\
\text { pneumoniae }\end{array}$ & 0 & - & 0 & - & 1 & $(1.5)$ \\
\hline Streptococcus specie & 0 & - & 0 & - & 1 & $(1.5)$ \\
\hline Enterococcus durans & 0 & - & 0 & - & 1 & $(1.5)$ \\
\hline Enterobacter aerogenes & 0 & - & 0 & - & 1 & $(1.5)$ \\
\hline $\begin{array}{l}\text { Sphingomonas } \\
\text { paucimobilis }\end{array}$ & 0 & - & 0 & - & 1 & $(1.5)$ \\
\hline Total & $36 *$ & $(100.0)$ & $45 * *$ & $(100.0)$ & $65 * * *$ & $(100.0)$ \\
\hline
\end{tabular}

SBP: spontaneous bacterial peritonitis. * 33 cases, 3 polymicrobial; ** 43 cases, 2 polymicrobial; *** 58 cases, 7 polymicrobial

E. faecalis, another Gram-positive coccus with some frequency in SBP, presented a 50\% resistance rate to gentamicin in the third period, however, it showed an improvement in the resistance profile for ciprofloxacin from the first to the third evaluated period, maintaining the sensitivity of $100 \%$ for vancomycin. Unlike $E$. faecalis, which showed $100 \%$ sensitivity to ampicillin at all periods, cases of $E$. faecium showed resistance to ampicillin by $60 \%$ and to ciprofloxacin by $80 \%$.

Considering the Gram-negative germs, a less bleak scenario is found in relation to $E$. coli, whose antimicrobial resistance only migrated from 0 to $14 \%$ in relation to the 3 rd generation cephalosporins, piperacillin/tazobactam and ciprofloxacin in the three periods. Nevertheless, K. pneumoniae presented resistance rates of $66 \%$ for these antibiotics in the second and $73 \%$ in the third period, about three times higher than those presented in the first period; also developing resistance to the imipenem of $45 \%$ in the third period evaluated, drug for which there was no resistance in the first two periods. 
TABLE 2. Bacterial resistance rates in SBP in the first (1997-1998), second (2002-2003) and third (2014-2015) periods evaluated

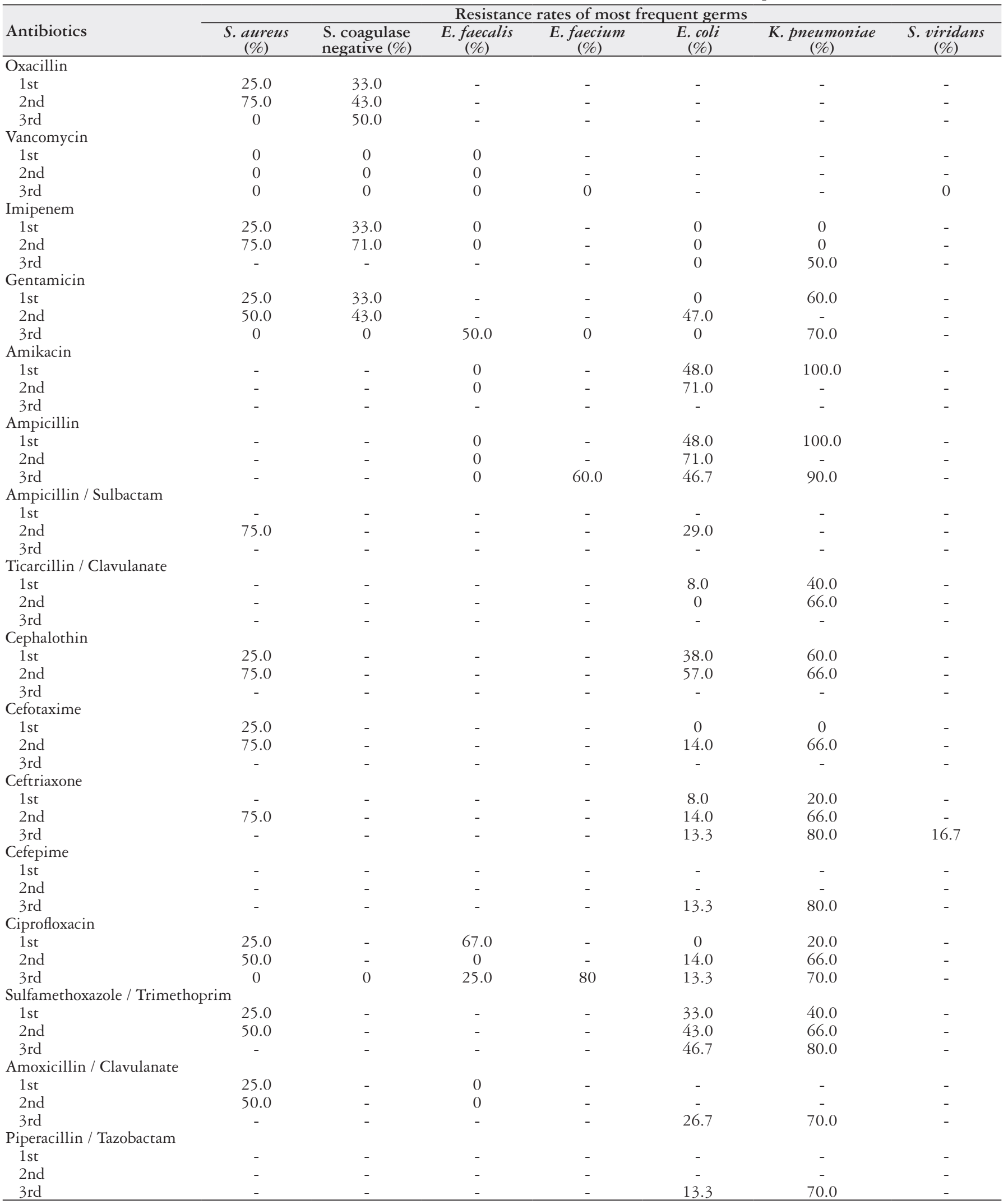

SBP: spontaneous bacterial peritonitis. S coagulase: Staphylococus coagulase. (-) not tested. 


\section{DISCUSSION}

The present study showed a modification of the bacterial flora causing SBP in the last 17 years in a reference hospital in Southern Brazil, detecting a significant alternating pattern of predominance between Gram-negative and Gram-positive organisms over time.

Bacterial infections are frequent in patients with decompensated cirrhosis, and may promote increased morbidity and mortality ${ }^{(3)}$. Management of cirrhotic patients with severe complications has spread, particularly with the expansion of liver transplantation programs and invasive procedures used in this setting ${ }^{(2)}$, which may also be associated with infections ${ }^{(10)}$. Similarly, another responsible factor can be the selective intestinal decontamination with norfloxacin, that has been widely used in primary and secondary prophylaxis of $\mathrm{SBP}^{(3,5)}$

All these factors may have influenced the modifications in the flora and the resistance of SBP-causing germs in cirrhotic patients ${ }^{(2-4)}$. This change in the profile of patients and pathogens should be carefully monitored, since it has a direct implication in the empirical choice of antimicrobials.

In the present study, both ciprofloxacin and third-generation cephalosporins were observed to maintain good antimicrobial activity over some Gram-negatives, such as E. coli, which was resistant in only $14 \%$ of the sample in the second and third periods evaluated. It should be noted, however, that none of the patients were on prophylactic use of norfloxacin.

Many authors ${ }^{(11-13)}$ have shown an increase in the prevalence of infections caused by multi-resistant bacteria, especially in nosocomial episodes, presenting resistance to third-generation cephalosporins of $21.5 \%$ to $45 \%$. Taking into account the increasing evidence for multiresistance among the bacteria that cause SBP and the lower efficacy of treatment with third-generation cephalosporins, new treatment recommendations have become necessary for the management of infections in cirrhotic patients. The distinction between community-acquired infectious episodes, healthcareassociated or nosocomial infections, and the identification of risk factors for multiresistant germs can help in the decision-making process for empirical antibiotic therapy choice ${ }^{(14)}$.

Regarding Klebsiella, a Gram-negative bacteria also prevalent in this series, attention is drawn to the development of antimicrobial resistance in the order of $66 \%$ to $80 \%$ for third generation cephalosporins in the second and maintaining in the third periods. In addition, resistance to imipenem appeared in the third period, which had not been observed in previous periods.

Piano et al. ${ }^{(15)}$ presented a prospective randomized study which compared the effectiveness of third-generation cephalosporin, ceftazidime, versus meropenem plus daptomycin. The authors discussed the possible concerns of starting highest broad-spectrum antibiotics as a first line treatment might possibly increase the risk of more resistant bacteria in the hospitalized patients. They recommended that based on the early results of cultures, antibiotics may be tailored to narrow-spectrum drugs and this approach may partially overcome this problem.

There were also increased cases of SBP by Gram-positive cocci in the second period, with S. coagulase-negative and S. aureus being relevant, although none of the patients had used prophylactic antibiotics prior to the occurrence of SBP. More significantly, its resistance profile increased from $25 \%$ to $50 \%$ to $75 \%$ for all drugs tested, including third generation cephalosporins, except for vancomycin. In the third period, staphylococci were not frequent germs.
Enterococci and streptococci, not frequent germs found in the first and second periods, were more prevalent in the third, corresponding to $30.9 \%$ of SBP cases. It is worth noting that while the resistance of $E$. faecalis and Streptococcus is small relative to the antibiotics commonly tested, the resistance of $E$. faecium was $60 \%$ to ampicillin. In contrast to streptococcus species, enterococci are frequently resistant to penicillin with a minimum inhibitory concentration (MIC) of $1-8 \mu \mathrm{g} / \mathrm{mL}$ for $E$. faecalis and $16-64 \mu \mathrm{g} /$ $\mathrm{mL}$ for $E$. faecium $^{(16)}$. In a study by Friedrich $\mathrm{K}$ et al. ${ }^{(17)}, 88.6 \%$ of all Enterococcus spp. agents were resistant to third-generation cephalosporins and 80.6\% were resistant to carbapenems, $62.9 \%$ of the patients with Enterococcus-related SBP received ineffective empirical antibiotic treatment. These antimicrobial resistance patterns might explain the observed association for SBP infection with Enterococcus spp. and poor patient survival $(P=0.048)$, which was not present for infection with Streptococci, Staphylococci, Enterobacteriaceae, or Candida.

The trend of increased participation of Gram-positive cocci in severe bacterial infections of hospitalized cirrhotic patients, not only in the form of SBP, but also and especially in the form of bacteremia, has been emphasized ${ }^{(3,10,18)}$. The clinical value and significance of species of coagulase-negative staphylococci obtained in the most diverse biological materials continues to increase as diagnostic and therapeutic strategies lead to a growing proportion of invasive procedures ${ }^{(19)}$. Immunocompromised hospitalized patients constitute the population most vulnerable to these types of pathogens. However, identifying them as etiological agents or contaminating flora continues as a strong challenge ${ }^{(19)}$.

When addressing the progression of Gram-positive and Gram-negative bacteria across the three periods, we identified a significant non-linear variation over time. A possible hypothesis to explain these findings could be a seasonality to the alternation of predominance between Gram-negative and Gram-positive germs, which is consistent with the expected dynamic balance of nosocomial bacterial populations.

As possible limitations of the study, we can mention the retrospective design, which could limit the obtaining of some data. In addition, because it has been performed in a single center, the external validity may be limited, and similar studies in other hospitals should be performed.

In conclusion, there was a modification of the bacterial population causing SBP, with high frequency of Gram-positive organisms, as well as an increase in the resistance to the traditionally recommended antibiotics. Future research should focus on the clinical effectiveness of empiric Gram-negative and Gram-positive antibiotic coverage for at-risk cirrhotic patients. An imminent extension in treatment protocols to include empiric Gram-positive antibiotic coverage for SBP in centers with similar flora may be considered. The precise timing of this change in therapeutics should be guided by local epidemiological surveillance.

\section{Authors' contributions}

Almeida PRL and Tovo CV conceptualized and designed the study; Leão GS and Gonçalves CDG collected the data; Leão GS, Gonçalves CDG and Picon RV analyzed the data; Almeida PRL, Tovo CV, Leão GS and Gonçalves CDG wrote the manuscript; Almeida PRL and Tovo CV reviewed the manuscript critically for important intellectual content; all authors approved the final version of the manuscript. 
Almeida PRL, Leão GS, Gonçalves CDG, Picon RV, Tovo CV. Impacto das mudanças da microbiologia na peritonite bacteriana espontânea em três diferentes períodos ao longo de 17 anos. Arq Gastroenterol. 2018;55(1):23-7.

RESUMO - Contexto - A peritonite bacteriana espontânea é uma complicação séria em pacientes cirróticos e as alterações nas características microbiológicas relatadas nos últimos anos podem afetar a escolha do antibiótico utilizado no tratamento. Objetivo - Os objetivos do presente estudo são avaliar as mudanças na epidemiologia e perfil de resistência bacteriana dos germes causadores de peritonite bacteriana espontânea em três períodos diferentes ao longo de 17 anos. Métodos - Todos os pacientes cirróticos com peritonite bacteriana espontânea e cultura positiva de fluido ascítico foram estudados retrospectivamente em um hospital de referência no Sul do Brasil. Foram avaliados três diferentes períodos selecionados de forma randômica: 1997-1998, 2002-2003 e 2014-2015. Os organismos infecciosos mais frequentes e a sensibilidade in vitro a antibióticos foram registados. Resultados - No primeiro período (1997-1998) houve 33 casos; os mais comuns foram: E. coli em 13 (36,1\%), Staphylococcus coagulase-negativo em $6(16,7 \%)$, K. pneumoniae em 5 (13,9\%), S. aureus em $4(11,1 \%)$ e $S$. faecalis em $3(8,3 \%)$. No segundo período (2002-2003), houve 43 casos, os mais frequentes foram: Staphylococus coagulase-negativo em 16 (35,5\%), S. aureus em 8 (17,8\%), E. coli em 7 (15,5\%) e K. pneumoniae em $3(6,7 \%)$. No terceiro período (2014-2015), houve 58 casos (sete com duas bactérias), os mais frequentes foram: E. coli em 15 (23,1\%), S. viridans em 12 (18,5\%), K. pneumoniae em $10(15,4 \%)$ e E. faecium 5 (7,7\%). Nenhum paciente estava usando profilaxia antibiótica. Quando considerados todos os estafilococos, a prevalência aumentou para taxas da ordem de 50\% no segundo período, apresentando redução no terceiro período avaliado. Do mesmo modo, a prevalência de E coli resistente aumentou, chegando a 14\%. Conclusão - Houve modificação da população bacteriana causadora de peritonite bacteriana espontânea, com alta frequência de organismos gram-positivos, bem como aumento da resistência aos antibióticos tradicionalmente recomendados. Este estudo sugere uma provável inclusão iminente de um medicamento contra organismos gram-positivos no tratamento empírico da peritonite bacteriana espontânea.

DESCRITORES - Peritonite. Infecções bacterianas. Cirrose hepática. Ascite.

\section{REFERENCES}

1. Mowat C, Stanley A. Spontaneous bacterial peritonitis - diagnosis, treatment and prevention. Aliment Pharmacol Ther. 2001;15:1851-9.

2. Fernández J, Bauer TM, Navasa M, Rodés J. Diagnosis, treatment and prevention of spontaneous bacterial peritonitis. Baillieres Best Pract Res Clin Gastroenterol. 2000;14:975-90.

3. Fernández J, Navasa M, Gómez J, Colmenero J, Vila J, Arroyo V, Rodés J. Bacterial infections in cirrhosis: epidemiological changes with invasive procedures and norfloxacin prophylaxis. Hepatology. 2002;35:140-8.

4. Rimola A, García-Tsao G, Navasa M, Piddock LJ, Planas R, Bernard B, Inadomi JM. Diagnosis, treatment and prophylaxis of spontaneous bacterial peritonitis: a consensus document. J Hepatol. 2000;32:142-53.

5. Such J, Runyon B. Spontaneous bacterial peritonitis. Clin Infect Dis. 1998;27:669-76.

6. Wiest R, Krag A, Gerbes A. Spontaneous bacterial peritonitis: recent guidelines and beyond. Gut. 2012;61:297-310.

7. Kim JH, Jeon YD, Jung IY, Ahn MY, Ahn HW, Ahn JY, et al. Predictive factors of spontaneous bacterial peritonitis caused by gram-positive bacteria in patients with cirrhosis. Medicine (Baltimore). 2016;95:e3489.

8. Alexopoulou A, Papadopoulos N, Eliopoulos DG, Alexaki A, Tsiriga A, Toutouza $\mathrm{M}$, Pectasides D. Increasing frequency of gram-positive cocci and gram-negative multidrugresistant bacteria in spontaneous bacterial peritonitis. Liver Int. 2013;33:975-981.

9. Almeida PRL, Camargo NS, Arenz M, Tovo CV, Galperim B, Behar P. Peritonite bacteriana espontânea: impacto das mudanças da microbiologia. Arquivos de Gastroenterologia. 2007;44:68-72.

10. Wong F, Bernardi M, Balk R, Christman B, Moreau R, Garcia-Tsao G, Patch D, Soriano G, Hoefs J, Navasa M. Sepsis in cirrhosis: report on the 7th Meeting of the Internal Ascites Club. Gut. 2005;54:718-25.
11. Ariza X, Castellote J, Lora-Tamayo J, Girbau A, Salord S, Rota R, Ariza J, Xiol X. Risk factors for resistance to ceftriaxone and its impact on mortality in community, healthcare and nosocomial spontaneous bacterial peritonitis. $\mathrm{J}$ Hepatol. 2012;56:825-32.

12. Tandon P, Delisle A, Topal JE, Garcia-Tsao G. High prevalence of antibiotic-resistant bacterial infections among patients with cirrhosis at a US liver center. Clin Gastroenterol Hepatol. 2012;10:1291-1298.

13. Fernández J, Gustot T. Management of bacterial infections in cirrhosis. J Hepatol. 2012;56 (Suppl 1): S1-12.

14. Mattos AA, Costabeber AM, Lionço LC, Tovo CV. Multi-resistant bactéria in spontaneous bacterial peritonitis: a new step in the management? WJG. 2014;20:14079-86.

15. Piano S, Fasolato S, Salinas F, Romano A, Tonon M, Morando F, et al. The empirical antibiotic treatment of nosocomial spontaneous bacterial peritonitis: results of a randomized, controlled clinical trial. Hepatology. 2016; 63:1299-309.

16. Klibi N, Ben Slama K, Sáenz Y, Masmoudi A, Zanetti S, Sechi LA, Boudabous A, Torres C. Detection of virulence factors in high-level gentamicin-resistant Enterococcus faecalis and Enterococcus faecium isolates from a Tunisian hospital. Can J Microbiol. 2007;53:372-9.

17. Friedrich K, Nüssle S, Rehlen T, Stremmel W, Mischnik A, Eisenbach C. Microbiology and resistance in first episodes of spontaneous bacterial peritonitis: implications for management and prognosis. J Gastroenterol Hepatol. 2016;31:1191-5.

18. Campillo B, Dupeyron C, Richardet JP, Mangeney N, Leluan G. Epidemiology of severe hospital-acquired infections in patients with liver cirrhosis: effect of long-term administration of norfloxacin. Clin Infec Dis. 1998;26:1066-70.

19. Kloosi WE, Bannerman TL. Update on clinical significance of coagulase-negative staphylococci. Clin Microbiol Rev. 1994;7:117-40. 